\title{
Bioactive compounds and quality characteristics of five apples cultivars
}

\author{
Compostos bioativos e características de qualidade de cinco cultivares de maçãs
}

\author{
Moises Zucoloto ${ }^{\mathrm{I}}$ Kang-Mo Ku ${ }^{\mathrm{II}}$ Mosbah M. Kushad ${ }^{\mathrm{II}}$ Jamal Sawwan $^{\mathrm{III}}$
}

\begin{abstract}
The aim of this study was to evaluate bioactive compounds in five apple cultivars and to analyze correlation of their quality characteristics with concentration of bioactive compounds. Phenolic compounds measurements were made in a spectrophotometer compared to a standard curve of gallic acid and expressed as gallic acid equivalent (GAE) per $100 \mathrm{~g}$ of dry weight. Sugar and organics acids in five cultivars were quantified using high-performance liquid chromatograph (HPLC). Antioxidant activities were evaluated using three complementary tests 2,2-diphenyl-1-picrylhidrazyl (DPPH) scavenging activity, ferric reducing antioxidant power (FRAP), and 2,2'-azino-bis (3-ethylbenzthiazoline-6-sulfonic acid) (ABTS). 'GoldRush' had the highest total phenolic compared to the other four cultivars. Additionally, 'GoldRush' had slightly higher, DPPH activity followed by 'Crimson Crisp' and 'Wine Crisp'. 'GoldRush' and 'Crimson Crisp' cultivars also have higher antioxidant capacity based on the ABTS and FRAP methods. The antioxidant capacity was significantly correlated with total polyphenols present in the different cultivars, while organic acids and fruit color showed slightly significant correlation to total phenols.
\end{abstract}

Key words: Mallus domestica, organic acids, sugar, antioxidant capacity, HPLC/DAD.

\section{RESUMO}

O objetivo do estudo foi de analisar compostos bioativos e correlacioná-los com características de qualidade em cinco cultivares de maçãs. Os compostos fenólicos foram mensurados com espectrofotometro, comparando-se a curva padrão de ácido gálico e expressos em acido gálico equivalente por $100 \mathrm{~g}$ de matéria seca. Os açúcares e ácidos orgânicos foram quantificados por meio de HPLC. A capacidade antioxidante foi mesurada por meio de três métodos: 2,2-diphenyl-1- picrylhidrazyl (DPPH), poder antioxidante de redução do ion ferro (FRAP) e 2,2'-azino-bis(3-ethylbenzthiazoline-6-sulfonic acid) (ABTS). A cultivar 'GoldRush'foi a que apresentou maiores valores de polifenóis totais, quando comparada com as demais cultivares, e também maior capacidade antioxidante pelo método DPPH, seguida pela cultivar 'Crimson Crisp' and 'Wine Crisp'. 'GoldRush' and 'Crimson Crisp' foram os que apresentaram os maiores valores da capacidade antioxidante por meio dos métodos ABTS e FRAP. A capacidade antioxidante apresentou correlação significativa com polifenóis totais, já os ácidos orgânicos e cor da epiderme apresentaram correlação com os polifenóis totais.

Palavras-chave: Mallus domestica, ácidos orgânicos, açúcares, capacidade antioxidante, HPLC/DAD.

\section{INTRODUCTION}

Degenerative diseases such as cancers, Alzheimer's, and cardiovascular disease pose grave threats to public health. These illnesses can require expensive, lengthy treatment which may still fail to restore patient health. Thus, preventative measures are our best and first defense against degenerative disease. Consumption of foods rich in bioactive compounds have been found to reduce some these diseases (TONG et al., 2011). This is due to the food's antioxidants including vitamins $\mathrm{C}$ and $\mathrm{E}$, carotenoids, and polyphenols. Antioxidants prevent the occurrence of free radical damage in the cell (BAGETTI et al., 2011).

\footnotetext{
'Departamento de Ciências Agrárias e Biológicas, Universidade Federal do Espírito Santo (UFES), Rodovia BR 101, km 60, 29932-540, São Mateus, ES, Brasil. E-mail: moiseszucoloto@hotmail.com. Corresponding author.

IDepartment of Crop Science, University of Illinois at Urbana-Champaign, Urbana, IL, USA.

III Department of Faculty of Agricultural and Food Sciences, American University of Beirut, Office of Institutional Research and Assessment (OIRA), Riad El-Solh/Beirut, Lebanon.
} 
Recent work has shown that there are considerable variations of bioactive compounds in apples (DROGOUDI et al., 2008; WOJDYLO et al., 2008). The main factor is related to genetic variability among different cultivars. The such as, skin color, the environmental conditions during production, such as, temperature, sunlight, and irrigation, also influence (DROGOUDI et al., 2008). WOJDYLO et al. (2008) evaluated old and new apple cultivars produced in Poland. They observed significantly higher concentration of bioactive compounds in newly developed cultivars. This suggests that antioxidant content is a trait which can, and should be manipulated by breeders.

Given the ability of functional foods to reduce degenerative disease, it would be valuable to determine which easily visible characteristics are indicators of their antioxidant capacity. For example, previous work has shown a correlation between the pomegranate's nutritional value and its readily apparent physical properties of color and size (DROGOUDI et al., 2005). There are countless apple cultivars available, and new cultivars are being continuously developed and introduced commercially. To help meet the needs of public health, we evaluated bioactivity of four newly released apple cultivars developed by the Purdue, Rutgers, and Illinois (PRI) breeding program. We then compared it with the older, widely consumed cultivar 'Golden Delicious'. Finally, we analyzed the relationship between biochemical properties and readily apparent fruit characteristics.

\section{MATERIALS AND METHODS}

Fruit from six-year old 'Golden Delicious', 'GoldRush', 'Wine Crisp', 'Pixie Crunch', and 'Crimson Crisp' trees grafted on 'Budagovsky 9' were harvested at optimum commercial maturity. Trees are grown at the fruit farmer of the University of Illinois, Champaign-Urbana. Average size fruits free of any visual damage were harvested. Fruits were kept stored at $0^{\circ} \mathrm{C}$ for one week then evaluated after seven days at room temperature.

Ten fruits of four replicates were used to determine each parameter. After measurement of quality indices, fruits were subsampled by taking wedges of about $700 \mathrm{~g}$ per replicate of each cultivar and stored at $-18^{\circ} \mathrm{C}$ overnight prior to freeze-drying.

The color of the peel was carried out individually in the equatorial region of the fruit with digital colorimeter Model CR-200 (Konica Minolta, Osaka, Japan). The color values were obtained from the $\mathrm{L}^{*} \mathrm{a}^{*} \mathrm{~b}^{*}$ and the hue angle and chroma $\left(\mathrm{C}^{*}\right)$ used arctan the formulas $\left(\mathrm{b}^{*} / \mathrm{a}^{*}\right)$ and $\left(\mathrm{a}^{* 2}+\mathrm{b}^{* 2}\right)^{1 / 2}$. Cultivars 'Wine Crisp' and 'Pixie Crunch' were performed color readings in the region yellow and red.

To measure the TA, $\mathrm{pH}$ and SS content was used homogenized juice of all fruits of each repetition. TA values were determined by titrating juice samples with $0.1 \mathrm{M} \mathrm{NaOH}$ and expressed as g malic acid 100 $\mathrm{mL}^{-1}$ juice. $\mathrm{pH}$ values were measured with a $\mathrm{pH}$ meter (Fisher Science Education, Malaysia). For measure the SS content was used analog Leica 10430 refractometer (Fisher Scientific, Waltham, MA, USA).

Freeze-drying was done in a VirTis freeze dryer (VirTis, Gardiner, New York, USA) to dry at $40 \mathrm{mmHg}$ ). Freeze-dried samples were ground in coffee grinder and analyzed for total phenolic, antioxidants capacity, sugar, and organic acids as follows procedures.

For extraction of polyphenols approximately $0.5 \mathrm{~g}$ of freeze dried tissue samples were combined with $20 \mathrm{~mL}$ of $70 \%$ methanol and homogenized in a Polytron homogenizer (Kinematica Ag Littau, Switzerland) set at a speed of 4 about 1 minute. The homogenate was centrifuged twice for 10 minutes at $4000 \mathrm{~g}$. The supernatant was collected and used to determine total phenolic (TP) using the colorimetric Folin-Ciocalteu assay as described by SINGLETON et al. (1999). Tissue TP measurements were made in a Shimadzu spectrophotometer set at $725 \mathrm{~nm}$ compared to a standard curve of gallic acid and expressed as gallic acid equivalent (GAE) per $100 \mathrm{~g}$ of dry weight.

The antioxidant capacity was determined by the modified 2,2-Diphenyl-1-picrylhidrazyl (DPPH) radical method (BRAND-WILLIAMS et al., 1995) which is based on the quantification of free radical-scavenging activity, with modifications according to RUFINO et al. (2007). One $g$ of freeze dried tissue were in centrifuge tubes and extracted sequentially with $20 \mathrm{ml}$ of methanol/water (50:50, $\mathrm{v} / \mathrm{v}$ ) at room temperature for $1 \mathrm{~h}$. The tubes were centrifuged at $25000 \mathrm{~g}$ for $15 \mathrm{~min}$ and the supernatant was recovered. Then $20 \mathrm{ml}$ of acetone/water (70:30, $\mathrm{v} / \mathrm{v}$ ) was added to the residue at room temperature, extracted for $60 \mathrm{~min}$ and centrifuged. Methanol and acetone extracts were combined, made up to $50 \mathrm{ml}$ with distilled water and used to determine antioxidant capacity. A methanol solution containing $0.06 \mathrm{mM}$ DPPH was prepared. After adjusting the blank with methanol, an aliquot of $100 \mu \mathrm{l}$ of fruit extract was added to $3.9 \mathrm{ml}$ of this solution. Based on preliminary study, the times required to obtain DPPH was after two hours of contact of the sample with the reagent. The antioxidant capacity was expressed $\mathrm{mM}$ DPPHas the concentration of 
antioxidant required to reduce the original amount of free radicals by $50 \%\left(\mathrm{EC}_{50}\right)$ and values expressed as $\mathrm{EC}_{50}=\mathrm{g}^{-1}$ dry weight $\mathrm{mg}^{-1} \mathrm{DPPH}$.

Antioxidant capacity was also evaluated by 2,2 '-azino-bis (3-ethylbenzthiazoline-6-sulfonic acid) (ABTS) and ferric reducing antioxidant power (FRAP) method according KU et al. (2011). Briefly the ABTS method involved dissolving $7 \mathrm{mM}$ ABTS (ammonium salt) in potassium phosphate buffer (pH 7.4) and combined with $2.45 \mathrm{mM}$ potassium persulfate. The mixture was stored in the dark for $10 \mathrm{~min}$. The dark blue solution was diluted with potassium phosphate buffer $(\mathrm{pH}$ 7.4) until the absorbance reached $1.0 \pm 0.02$ at $734 \mathrm{~nm}$ using a microplate reader (Biotek Instruments, Winooski, USA). Two hundred $\mu \mathrm{L}$ of the resulting solution was mixed with $10 \mu \mathrm{L}$ of the sample, and 6 min later the absorbance was recorded at room temperature. The results were expressed as Trolox equivalent (TE $\mathrm{mM} \mathrm{g}{ }^{-1}$ dry weight). The concentration of standard solution ranged from 0.25 to $4 \mathrm{mM}$. All experiments were carried out in triplicate.

The FRAP method involves mixing $200 \mu \mathrm{L}$ of freshly prepared FRAP reagent with $10 \mu \mathrm{L}$ of the previously prepared extract. The FRAP reagent contained $2.5 \mathrm{~mL}$ of a $10 \mathrm{mM} \mathrm{L}^{-1}$ TPTZ solution in $40 \mathrm{mM} \mathrm{L}^{-1} \mathrm{HCl}$ in distilled water, $2.5 \mathrm{~mL}$ of $20 \mathrm{mM}$ $\mathrm{L}^{-1} \mathrm{FeCl}_{3} \cdot 6 \mathrm{H}_{2} \mathrm{O}$ in distilled water, and $25 \mathrm{~mL}$ of $0.3 \mathrm{M}$ $\mathrm{L}^{-1}$ acetate buffer of $\mathrm{pH}$ 3.6. The absorbance was measured at $593 \mathrm{~nm}$ after $6 \mathrm{~min}$ on a microplate reader. The results were expressed as Trolox equivalents (TE $\mathrm{mM} \mathrm{g}^{-1}$ of dry weight). The concentrations of standard solution ranged from 0.25 to $2 \mathrm{mM}$. All experiments were carried out in triplicate.

To determination sugars content, $0.2 \mathrm{~g}$ of freeze-dried tissue samples were placed in thimbles inside $20 \mathrm{~mL}$ test tubes, and $2 \mathrm{~mL}$ of $70 \%$ ethanol was added to each tube. A $1 \mathrm{~cm}$ marble was placed on the mouth of each tube to trap the evaporated ethanol. The tubes were heated on a hot plate (Pierce ReactioTherm III, Rockford, USA) for four hours at $90^{\circ} \mathrm{C}$. The ethanol fraction was collected and evaporated under an air stream and the dried residue was brought up $1 \mathrm{~mL}$ with distilled water. The aqueous extract was filtered through a $0.2 \mu \mathrm{m}$ nylon filter and $60 \mu \mathrm{L}$ sample was injected into a Hitachi HPLC (Tokyo, Japan), equipped with a refractive index detector and a column heater. Glucose, fructose, sucrose, and sorbitol were separated using a REZEX 10 micron $8 \% \mathrm{Ca}, 300 \times 7.80 \mathrm{~mm}$ column (Torrance, CA, USA) heated at $80^{\circ} \mathrm{C}$. Glass distilled water was used as a mobile phase at a flow rate of $0.6 \mathrm{~mL} \mathrm{~min}^{-1}$. Sugar concentration was expressed as $\mathrm{g} 100 \mathrm{~g}^{-1}$ dry weight.
Organic acid extraction was carried out by weighing a $1.0 \mathrm{~g}$ of freeze-dried tissue samples. Dried tissue were ground with a mortar and pestle, placed into a $20 \mathrm{~mL}$ tubes, and combined with $5 \mathrm{~mL}$ of $0.004 \mathrm{~N} \mathrm{H}_{2} \mathrm{SO}_{4}$. The tissue was homogenized in the dark with a Polytron homogenizer set at a speed of 4 about 1 minute. The homogenate was centrifuged at a $27,000 \times \mathrm{g}$ at $5^{\circ} \mathrm{C}$ for $30 \mathrm{~min}$. A $1 \mathrm{~mL}$ fraction of the supernatant was filtered through a $0.2 \mu \mathrm{m}$ nylon filter and a $5 \mu \mathrm{L}$ fraction was injected into an a Hitachi HPLC equipped with a UV detector set at $210 \mathrm{~nm}$ and a Phenomenix organic acid column (REZEX 10 $\mu \%$ H., $300 \times 7.8 \mathrm{~mm})$. Sulfuric acid $(0.0004 \mathrm{~N})$ was used as a mobile phase at a flow rate of $0.700 \mathrm{~mL} \mathrm{~min}^{-1}$. Data were compared to athematic organic acids standards (malic, oxalic, and tartaric), and expressed as $\mathrm{mg}$ $100 \mathrm{~g}^{-1}$ dry weight. Ascorbic acid was determined using the method of NIELSEN et al. (2010). Resulted

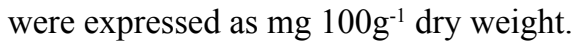

The experiment was set up as a randomized plot. Analysis of variance and correlation analysis between quality characteristics with the concentration of bioactive compounds were performed using SPSS 19.0 (SPSS Inc., Chicago, Illinois, USA). When statistically significant ( $F$-test), mean separation was performed using Tukey`s test.

\section{RESULTS AND DISCUSSION}

Total phenolic content and antioxidant activity in the five apple cultivars are presented in figure 1. There was a significant variation in total phenolic content among cultivars. The highest total phenolic content (1.90g GAE per $100 \mathrm{~g}^{-1}$ dry weight) were found in 'GoldRush', followed by 'Crimson Crisp', 'Wine Crisp', 'Golden Delicious', and 'Pixie Crunch', which had $(1.58 ; 1.53 ; 1.42 ; 1.14 \mathrm{~g}$ GAE per $100 \mathrm{~g}^{-1}$ dry weight) (Figure $\left.1 \mathrm{~A}\right)$. Our results are similar with previous studies (WOJDYLO et al., 2008; VALAVANIDIS et al., 2009). WOJDYLO et al. (2008) examined old and new apple varieties and reported that total polyphenols concentrations ranged between 0.5 and $2.7 \mathrm{~g} \mathrm{GAE}$ per $100 \mathrm{~g}^{-1}$ dry weight. VALAVANIDIS et al. (2009) examined total phenolics content in five apple cultivars ('Red Delicious Starking', 'Golden Delicius', 'Granny Smith', 'Royal Gala', and 'Jona Gold') and found that whole fruits contained between 0.1-0.2g GAE per $100 \mathrm{~g}^{-1}$ dry weight based on pulp weight and peels contained between 0.2-0.4g GAE per $100 \mathrm{~g}^{-1}$ dry weight.

Antioxidant capacity differed from five apple cultivars, but different analytical methods gave similar results (Figure 1B, 1C, 




and 1D). Determined via the DPPH method, the cultivars that had high antioxidant capacity were 'GoldRush', 'Wine Crisp' and 'Crimson Crisp' with $0.93,1.02$ and $1.06 \mathrm{EC}_{50}=\mathrm{g}_{\text {dry }}$ weight $\mathrm{mg}^{-1}$ DPPH, respectively. Cultivars 'Golden Delicious' and 'Pixie Crunch' showed the significantly higher values than above three apple cultivars which are 1.47 and $1.52 \mathrm{EC}_{50}=\mathrm{g}$ dry weight $\mathrm{mg}^{-1} \mathrm{DPPH}$, respectively. The values found in this study are similar of the WOJDYLO et al. (2008) that studied the antioxidant capacity from 67 apple varieties.

Antioxidant capacities obtained by the ABTS and FRAP were expressed in TE $\mathrm{mM} \mathrm{g}^{-1}$ dry weight. The both methods showed similar results among cultivars. The cultivars that had high antioxidant capacity by ABTS method was 'Gold Rush' and 'Crimson Crisp' (66.6 and 63.5TE mM g-1 dry weight) followed by cultivars 'Wine Crisp' and 'Golden Delicious' with intermediate values (52.40 and 55.37TE $\mathrm{mM} \mathrm{g}^{-1}$ dry matter) and 'Pixie Crunch' (45.80 $\mathrm{TE} \mathrm{mM} \mathrm{g}^{-1}$ dry weight) with lower value (Figure 1C). Determined via the FRAP method, the cultivar 'GoldRush' and the 'Crimson Crisp' also had higher antioxidant capacity 61.77 and $54.39 \mathrm{mM} \mathrm{g}^{-1}$ dry weight. The cultivar 'Pixie Crunch' had the lowest antioxidant capacity by ABTS and FRAP methods. However, it was not statistically different from the cultivar 'Golden Delicious' as measured by the FRAP assay (Figure 1D). Although statistical differences among cultivars vary between the two methods, the assay results were generally similar for different cultivars because these methods are based on electron transfer mechanism. Due to these variations, it is recommended to have at least two antioxidant methods with different modes of actions in study to accurately reflect the antioxidant activity (OZGEN et al., 2006).

The sugar, acid and ratio are closely related with the taste and flavor of the apple fruit. The 
fruit acid is beneficial for human body (HECKE et al., 2006). Since apples are recommended for diabetic patients, the knowledge of the sugar content of various apple fruits is of crucial importance today (HECKE et al., 2006). Therefore, it is important to measure sugar and acids from new apple variety for consumers. The sugar content showed significant differences between cultivars (Figure 2). Generally, the cultivar 'Pixie Crunch' presented the highest values and 'Wine Crisp', the lowest values. Regarding the glucose content of fruit, the cultivar 'Pixie Crunch' presented the highest concentration but did not differ significant from cultivars 'Crimson Crisp' and 'GoldRush' (Figure 2A). The concentration of fructose showed similar behavior among cultivars, the exception was the cultivar 'Wine Crisp' that presented the lowest value among them (Figure 2B). Cultivars had sucrose distributions similar to the glucose distribution, highlighted by maximum values in 'Pixie Crunch' and the minimum in 'Wine Crisp' (Figure 2C), for both sugars. Sorbitol, despite having a much smaller portion compared to the others sugars, followed the same behavior among cultivars, with higher values given by 'Pixie Crunch' and the smallest by 'Wine Crisp' (Figure 2D). The data presented here show variation between cultivars similar to that found by STURM \& STAMPAR et al. (1999) that evaluated seasonal variation of sugars in apple in different growing systems.

The concentration of the various acids present in the different cultivars is shown in figure 3. Malic acid was the one with the highest concentration between acids studied (Figure 3A), demonstrating consistency because when evaluating the total acidity of apples, it is represented by the concentration of malic acid (DROGOUDI et al., 2008). The greatest levels of malic acid was found in 'Gold Rush' with $272 \mathrm{mg} 100 \mathrm{~g}^{-1}$ of dry weight and the lowest value in 'Pixie Crunch', with 192mg $100 \mathrm{~g}^{-1}$ of dry weight (Figure $3 \mathrm{~A}$ ).

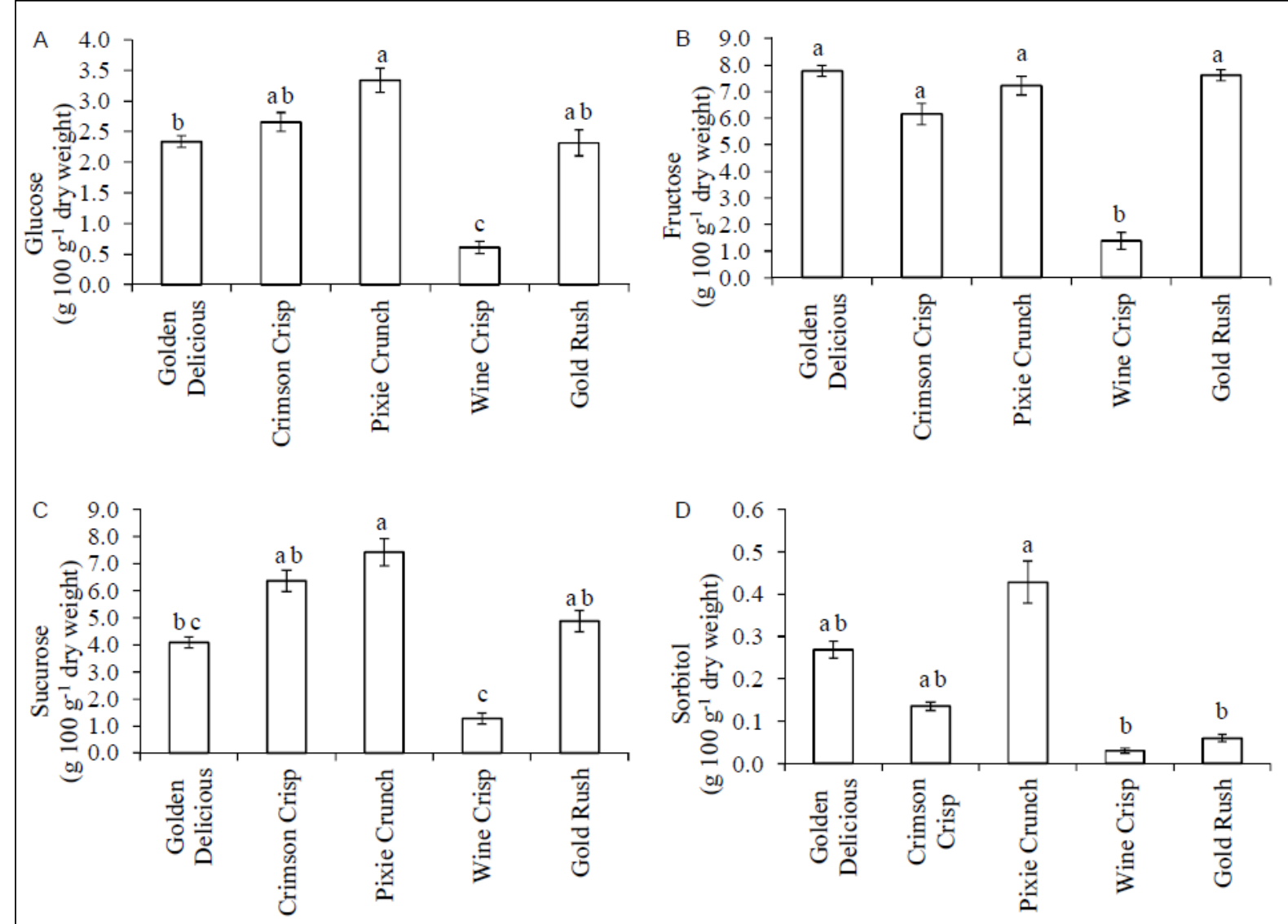

Figure 2 - Total sugars content (g 100 g-1 dry weight): glucose (A), fructose (B), sucrose (C) and, sorbitol (D) in tissues of five apple cultivars. Values represented mean \pm S.E. Different letters denote significant differences $(\mathrm{P} \leq 0.05)$. 



Figure 3 - Total acids organics contented (mg 100 g-1 dry weight): malic (A), oxalic (B), tartaric (C) and, ascorbic acid (D) in tissues of five apple cultivars. Values represented mean \pm S.E. Different letters denote significant differences $(P \leq 0.05)$.

Similar distributions of malate and oxalate were observed, but malic acid concentrations were a whole order of magnitude greater than oxalic acid concentrations (Figure 3B). Tartaric and ascorbic acids were present in relatively small amounts compared to malic acid. 'Golden Delicious' and 'GoldRush' had no detectable tartaric acid (Figure $3 \mathrm{C}$ ). The values of ascorbic acid (Figure 3D) of different cultivars evaluated are lower than found by JAN et al. (2012) who studied different cultivars of apple grown in Peshawar-Pakistan. They reported 'Red Delicious' contain $12.5 \mathrm{mg}$ of ascorbic acid of $100 \mathrm{~g}$ of fresh weight. The highest ascorbic acid was observed in 'Gold Rush' in this study but less than $4 \mathrm{mg}$ in $100 \mathrm{~g}$ of dry weight. The different ascorbic acid value may be due to the difference from the cultivar, environment, and extraction method. Ascorbic acid is an important quality characteristic of apple fruit because of its essentiality to human health, decreasing many diseases (TONG et al., 2011). SZETO et al. (2002) estimated that $100 \mathrm{mg}$ ascorbic acid is contained in one orange, a few strawberries, one kiwi fruit, 1-2 slices of pineapple, several florets of raw cauliflower or a handful of uncooked spinach leaves. However, ascorbic concentration of apple is lower than other fruits and vegetables (SZETO et al., 2002). Apples, bananas contain very little ascorbic acid (SZETO et al., 2002).

Although a significant correlation coefficient $(r=0.97)$ was observed between ABTS and FRAP methods, the DPPH method showed relatively smaller correlation negative coefficients with ABTS $(r=-0.78)$ and FRAP $(r=-0.85)$ methods (Table 1). The significant correlations among the three methods that showed consistent results indicate that antioxidant capacity of the different apples cultivars were reasonably determined.

There are several studies that verify the antioxidant capacity correlate with different quality indices, especially with polyphenols (WOJDYLO et al., 2008). In this study the polyphenolic content showed significant correlation coefficients with the values of $\operatorname{DPPH}(r=0.80)$, ABTS $(r=0.94)$, and FRAP $(r=0.97)$ as KHANIZADEH et al. (2007) have reported. In our 
Table 1 - Significant correlation coefficient values among colors parameters (L, C*, Hue), sugars, organics acids, phenolic contents, and antioxidant activities in five apples.

\begin{tabular}{|c|c|c|c|c|c|c|c|c|c|c|c|c|c|c|c|}
\hline & 1 & 2 & 3 & 4 & 5 & 6 & 7 & 8 & 9 & 10 & 11 & 12 & 13 & 14 & 15 \\
\hline 1. $\mathrm{L}$ & 1 & & & & & & & & & & & & & & \\
\hline 2. $\mathrm{C}^{*}$ & 0.66 & 1 & & & & & & & & & & & & & \\
\hline 3. Hue & 0.99 & 0.64 & 1 & & & & & & & & & & & & \\
\hline 4. Phenolic & - & 0.46 & - & 1 & & & & & & & & & & & \\
\hline 5. DPPH & - & - & - & 0.80 & 1 & & & & & & & & & & \\
\hline 6. Glucose & - & - & - & - & - & 1 & & & & & & & & & \\
\hline 7. Fructose & - & 0.64 & - & - & - & 0.88 & 1 & & & & & & & & \\
\hline 8. Sucrose & - & - & - & - & - & 0.97 & 0.78 & 1 & & & & & & & \\
\hline 9. Sorbitol & - & - & - & - & - & 0.50 & - & - & 1 & & & & & & \\
\hline 10. Oxalic & - & - & - & - & - & 0.53 & 0.66 & - & - & 1 & & & & & \\
\hline 11. Malic & - & - & - & 0.56 & - & - & - & -0.47 & - & - & 1 & & & & \\
\hline 12. Tartaric & -0.82 & - & -0.84 & - & 0.53 & 0.53 & - & 0.64 & - & - & - & 1 & & & \\
\hline 13. Ascorbic & - & 0.65 & - & - & - & - & - & - & - & 0.57 & - & - & 1 & & \\
\hline 14. ABTS & 0.45 & - & - & 0.94 & -0.78 & - & - & - & - & - & - & - & - & 1 & \\
\hline 15. FRAP & - & - & - & 0.97 & -0.85 & - & - & - & - & - & 0.52 & - & - & 0.97 & 1 \\
\hline Means & 51.79 & 36.75 & 68.20 & 1.52 & 1.20 & 2.25 & 6.03 & 4.80 & 0.18 & 9,89 & 250.60 & 1.57 & 2.86 & 56.74 & 49.44 \\
\hline
\end{tabular}

analysis, only malic and tartaric acids had significant correlation (0.53 and 0.52$)$ with antioxidant capacity obtained by DPPH and FRAP methods. DROGOUDI et al. (2008) also found a significant correlation between antioxidant capacity and acids in different cultivars of apple, but the authors obtained with ascorbic acid. In the study with pear, SÁNCHEZ et al. (2003) found weak correlation between antioxidant capacities and organic acids but chlorogenic acid (simple phenolic) showed a slight positive correlation.

The color of the peel of the fruit is generally correlated with antioxidant capacity. When assessing only the peels of the apple, the values for antioxidant activity are greater than whole apple or pulp of apple (KHANIZADEH et al., 2007; WOJDYLO et al., 2008). In the present study, only the characteristic L was significantly correlated with ABTS method $(r=0.45)$, indicating that ABTS method is sensitive to antioxidant compounds in lightness apple peel. Further correlation was not obtained due to the evaluations are carried out with peel and pulp, causing dilution of antioxidant compounds were present in higher quantities in the peel, since the peel corresponding to approximately $12 \%$ mass of apple fruits. The present analysis method using the whole apple fruit can be easily justified because most consumers eat the peel and pulp of apple fruits.

\section{CONCLUSION}

Among the apple cultivars we tested, 'GoldRush' had the highest total phenolic content.
Additionally, 'GoldRush' and 'Crimson Crisp' have shown greater antioxidant activity than cultivar 'GoldRush' in DPPH, ABTS, and FRAP methods. However, 'Pixie Crunch', has lower total phenolic and antioxidant ability in ABTS and FRAP, suggesting breeding program may need to focus on total phenolics and antioxidant compounds as well as other phenotype in the future. The antioxidant capacity was significantly correlated with polyphenols in this present study, while the organic acids showed little correlation. The ABTS antioxidant activity significantly correlated with L.

\section{ACKNOWLEDGEMENTS}

To Conselho Nacional de Desenvolvimento Científica e Tecnológico (CNPq), Coordenação de Aperfeiçoamento de Pessoal de Nível Superior (CAPES) and University of Illinois for the financial support. The authors appreciate Avery Shikanai's efforts for reviewing the manuscript in Department of Crop Sciences, University of Illinois at Urbana-Champaign.

\section{REFERENCES}

BAGETTI, M. et al. Physico chemical characterization and antioxidant capacity of pitanga fruits (Eugenia uniflora L.). Ciência Tecnologia Alimentos, v.31, p.147-154, 2011. Available from: <http://www.scielo.br/scielo.php?script=sci_arttext\& pid=S0101-20612011000100021>. Accessed: Ago. 05, 2014. doi:10.1590/S0101-20612011000100021.

BRAND-WILLIAMS, W. et al. Use of a free radical method to evaluate antioxidant activity LWT. Food Science and Technology, v.28, n.1, p.25-30, 1995. Available from: <http:// www.sciencedirect.com/science/article/pii/S0023643895800085>. Accessed: Ago. 05, 2014. doi:10.1016/S0023-64389580008-5.

Ciência Rural, v.45, n.11, nov, 2015. 
DROGOUDI, P.D. et al. Peel and fhesh antioxidant content and harvest quality characteristics of seven apple cultivars. Scientia Horticulture, v.115, p.149-153, 2008. Available from: <http:/ www.sciencedirect.com/science/article/pii/S0304423807002993>. Accessed: Ago. 05, 2014. doi:10.1016/j.scienta.2007.08.010.

DROGOUDI, P.D. et al. Physical and chemical characters in pomegranate. Hortscience, v.40, p.1200-1203, 2005. Available from: <http://pomologyinstitute.gr/en/files/ergasies/ PomegranateHortscience.pdf $>$. Accessed: Nov. 12, 2014.

HECKE, K. et al. Sugar-, acid- and phenol contents in apple cultivars from organic and integrated fruit cultivation European Journal of Clinical Nutrition, v.60, p.11361140, 2006. Available from: <http://www.nature.com/ejen/ journal/v60/n9/pdf/1602430a.pdf $>$. Accessed: Dec. 11, 2014. doi:10.1038/sj.ejen. 1602430 .

JAN, I. et al. Storage performance of apple cultivars harvested at different stages of maturity. Sarhad Journal Agriculture, v.28, n.2, p.219-225, 2012. Available from: <http://www.aup.edu.pk/ sj pdf/RESPONSE $\% 200 F \% 20$ APPLE $\% 20$ CULTIVARS $\% 20$ TO\%20DIFFERENT\%20STORAGE\%20-184-11-Horticulture. pdf $>$. Accessed: Ago. 05, 2014.

KHANIZADEH, S. et al. Phenolic composition and antioxidant activity of selected apple genotype. Journal Food Agriculture, v.5, n.1, p.61-66, 2007. Available from: <http://www. scientificjournals.org/journals2007/articles/1266.pdf $>$. Accessed: Dec. 11, 2014.

KU, K.M. et al. Antioxidant activity and quinone reductase inductive activity of pepper leaves in various leaf lengths of pepper leaves. Korean Journal of Horticultural Science \& Technology, v.28, p.120-125, 2010. Available from: <http:// www.cabi.org/cabdirect/FullTextPDF/2010/20103098060.pdf>. Accessed: Ago. 05, 2014.

NIELSEN, S.S. Food analysis laboratory manual. In: NIELSEN, S.S. Vitamin C Determination by indophenol method. New York: Springer, 2010. Cap.11, p.55-59.

OZGEN, M. etal. Modified2,2-azino-bis-3-ethylbenzothiazoline6-sulfonic acid (ABTS) method to measure antioxidant capacity of elected small fruits and comparison to ferric reducing antioxidant power (FRAP) and 2,2-diphenyl-1-picrylhydrazyl (DPHH) methods. Journal of Agricultural and Food Chemistry, v.54, p.151-1157, 2006. Available from: <http:// www.researchgate.net/publication/229983152>. Accessed: Dec. 11, 2014. doi: 10.1111/j.1365-2621.2009.01937.x.
RUFINO, M.S.M. et al. Medotologia científica: Determinação da atividade antioxidante toral em frutas pela captura do radical livre DPPH. Fortaleza: Embrapa Agroindústria Tropical, 2007. 4p. (Boletim Técnico, 127).

SÁNCHEZ, A.C.G. et al. Comparative study of six pear cultivars in terms of their phenolic and vitamin $\mathrm{C}$ contents and antioxidant capacity. Journal of the Science of Food and Agriculture, v.83, n.10, p.995-1003, 2003. Available from: $<$ http://onlinelibrary.wiley.com/doi/10.1002/jsfa.1436/full>. Accessed: Dec. 11, 2014

SZETO, Y.T. et al. Total antioxidant and ascorbic acid content of fresh fruits and vegetables: implications for dietary planning and food preservation. British Journal of Nutrition. v.87, n. 1, p.55-59, 2002. Available from: $<$ http://journals.cambridge.org/download.ph p?file $=\%$ 2FBJN\%2FBJN87 01\%2FS0007114502000089a.pdf\&c ode $=\mathrm{e} 50 \mathrm{c} 76873739 \mathrm{c} 27 \mathrm{f} 892 \mathrm{e} 95 \mathrm{a} 86818 \mathrm{a} 91 \mathrm{c}>$. Accessed: Dec. 11, 2014. doi:10.1079/BJN2001483.

SINGLETON, V.L. et al. Analysis of total phenols and other oxidation substrates and antioxidants by means of Folin-Ciocalteau reagent. Methods of Enzymology, v.299, p.152-178, 1999.

STURM, K.; STAMPAR, F. Seasonal variation of sugars and organic acids in apple (Malus domestica Borkh.) in different growing systems. Phyton, v.39, n.3, p.91-96, 1999. Available from: <http:// www.landesmuseum.at/pdf frei remote/PHY 393 0091-0096. pdf $>$. Accessed: Ago. 05, 2014.

TONG, H. et al. Purification, characterization and antioxidant activities in vitro and in vivo of the polysaccharides from Boletus edulis bull. Journal of Food Biochemistry, v.35, p.524-541, 2011. Available from: <http://www.mdpi.com/14203049/17/7/8079>. Accessed: Dec. 11, 2014. doi:10.1111/j.17454514.2010.00400.x.

VALAVANIDIS, A. et al. Polyphenolic profile and antioxidant activity of five apple cultivars grown under organic and conventional agricultural practices. International Journal of Food Science and Technology, v.44, p.1167-1175, 2009. Available from: <http://onlinelibrary.wiley.com/doi/10.1111/ j.1365-2621.2009.01937.x/full>. Accessed: Ago. 05, 2014. doi:10.1111/j.1365-2621.2009.01937.x.

WOJDYLO, A. at al. Polyphenolic compounds and antioxidant activity of new and old apple varieties. Journal of Agriculture Food Chemistry, v.56, p.6520-6530, 2008. Available from: $<$ http://www.mdpi.com/2076-3921/2/3/181/pdf > Accessed: Dec. 11 2014. doi:10.1021/jf800510j. 